\title{
THE BEGINNING OF SABBATH AND FESTIVALS IN ANCIENT JEWISH SOURCES
}

LUTZ DOERING

\section{Introduction}

The beginning of the Jewish Sabbath and festivals is a specific case of how the beginning of the day is reckoned and observed in Judaism. It is an issue of both ritual marking and Jewish Law, or halakhah, since both Sabbath and festivals require specific behavior and the abstention from certain activities. As to the general question of whether the day began with morning or evening, there is reason to assume that Jews in the Second Temple period, in particular in Palestine but arguably also in parts of the Diaspora, reckoned the day from evening to evening. To be sure, the reception of scripture implies some interaction with earlier reckoning from morning, as can be assumed for the sacrificial legislation in the Pentateuch, ${ }^{\mathrm{I}}$ but it can be shown that the textual corpus for which a start of the day with sunrise has most vigorously been claimed, the Dead Sea Scrolls, have adjusted the respective legislation to a reckoning from evening, possibly out of a tendency for consistency. ${ }^{2}$ Already the Hebrew Bible, outside sacrificial legislation in the strict sense, emphasizes the role of "evening" ( 'erev) in ritual contexts, as in the fast of Yom Kippur, which is to be held "on the ninth day of the [sc. seventh] month at evening, from evening to evening" (Lev 23:32). This points to a reckoning of the day from evening to evening ${ }^{3}$ but also raises the question of whether "evening" belongs to the previous day or the next. Further biblical texts suggest that the day was reckoned from evening in the postexilic period; ${ }^{4}$ in

${ }^{\mathrm{I}}$ E.g. Lev 7:I5, 22:30; cf. b. Hul. 83a. See Milgrom I99I-20IO: 4I 7-4I8, 420.

${ }^{2}$ Cf. Birenboim I998: 24I-244; Kister I999: 317-372, here: 339, 390-39I n. 207. Contra Talmon I958, 1960, 2003, 2004. I engage with Talmon's claims later, particularly at n. 49.

${ }^{3}$ Cf. Stern 200 I: I I2 n. 44; Niehr 1989: 363. See further Exod I2:I 8; Lev I 5:5-I I; Isa 30:29.

${ }^{4}$ Cf. Neh I3:I9; and Niehr I989: 363. 
fact, the "overwhelming majority of evidence from Second Temple times points to a reckoning of the day from sunset." 5

The present chapter takes its departure from this "overwhelming majority" and focuses on certain ambiguities concerning the precise time around sunset in which the day was taken to begin. It first looks at constructions of "evening" in ancient Jewish sources, especially at interpretations of the phrase "between the two evenings" that is given as the timing of two sacrifices in the Bible, the Passover sacrifice and the second daily offering $(\mathbb{2} 2)$. Next, we discuss texts dealing with a public announcement of the approach and end of the Sabbath that provide a framework for common Sabbath observance $(\$ 3)$. The chapter further investigates traditions in which a period of time prior to the beginning of the Sabbath is already invested with Sabbath-conforming behavior $(\$ 4)$ and confronts these with rabbinic texts that suggest that Jews used to do "labor" until very shortly before the onset of the day; these texts suggest that the Sabbath began at the end of evening twilight, which proved difficult to define $(\mathbb{S} 5) .^{6}$ Finally, the role of Sabbath evening meals is investigated, which initially began before the onset of the Sabbath and during which the participants experienced the transition from weekday to holy day $(\mathbb{S} 6)$.

\section{Between the Two "Evenings": bein ha- 'arbayim}

The relevant texts in the Pentateuch stipulate that both the second of the two daily sacrifices (tamid) and the slaughtering of the Passover animal are to be conducted bein ha-'arbayim, literally, "between the two evenings." The original meaning of the phrase is uncertain. Even though 'arbayim may originally have been an adverbial form, ${ }^{8}$ the preceding bein "between"

5 Ben-Dov and Saulnier 2008: 158 . In $\ 5$, we address the question of the precise start of day around "sunset." In his subsequent work, Saulnier claims that "there is solid evidence to suggest that in some traditions of the $364 \mathrm{DY}$ [364-day year] calendar the day was reckoned to start at sunrise" (Saulnier 20I 2: 2I6), although he does not adduce any new positive evidence for this claim but simply rehearses S. Talmon's relevant suggestions (see n. 49). His new hypothesis that the mishmarot texts from Qumran (4Q320, 4Q $32 \mathrm{I}$, and $4 \mathrm{Q}_{32 \mathrm{Ia}}$ ) correlate a reckoning of the day from morning with a lunar reckoning from evening is unconvincing in my view, but an engagement with it is beyond the scope of the present chapter.

${ }^{6}$ This explains why Roman-style sundials, which have been found on the Temple Mount in Jerusalem and elsewhere in Judea (cf. Ben-Dov 20II: 222-223 and fig. 6-7), would have been of little help for establishing the precise onset of Sabbath and festivals.

7 Exod 29:39, 4I; Num 28:4, 8 (tamid); Exod I2:6; Lev 23:5; Num 9:3, 5 (Passover); 9:I I (Second Passover). Cf. further Exod I6:I2 (meat in the desert); 30:8 (setting up of lamps by Aaron).

${ }^{8}$ Cf. Niehr 1989: 362. One may compare șohorayim, which denotes a point in time ("noon"). 
turns it into a dual. This may imply that one of the two "evenings" belongs with one day and the other one with the following day. More specifically, bein ha-'arbayim was initially taken as occurring at some point during twilight. ${ }^{9}$ Reflecting such an understanding, the Israelite Samaritans up to the present day slaughter the Passover shortly after sunset, except when Nisan I 5 is a Sabbath. ${ }^{\text {IO }}$ What sense did Jews in antiquity make of this phrase and how did they construe the respective "evenings"? It may be useful to start with the rendering of the phrase in the Septuagint. Most of the relevant

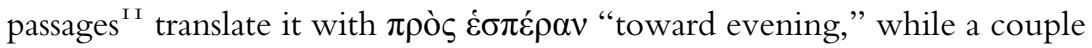
of others use $\tau$ ò $\delta \varepsilon \imath \lambda$ ivóv "at even"; ${ }^{22}$ neither of these reveals a particular interest in giving a precise time bracket or interpreting the peculiar wording of the Hebrew phrase. However, Lev 23:5, referring to Passover, deploys the

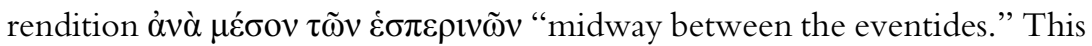
remains close to the Hebrew text. ${ }^{\text {I3 }}$

Philo of Alexandria tells his readers that the second tamid was brought

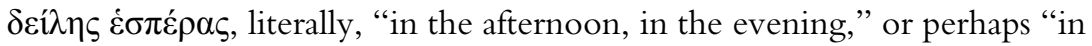
the early evening" (Spec. I:I69). Philo may here depend on the usual Septuagint timing for the tamid, "toward evening." While this will certainly have been before darkness, the precise timing of the sacrifice remains unclear. For Philo, the morning tamid is brought "for the benefactions of the daytime," the early evening one for those "of the night" (ibid.). Against the practical trend in late Second Temple Judaism (see presently), Philo maintains a close connection between the second tamid and nighttime. As to the time for the slaughtering of the Passover animals, Philo knows a wider

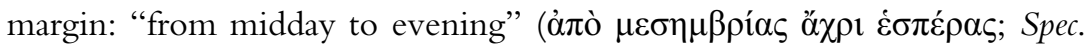
2:I45). As we shall see, Philo appears to share a notion of "between the evenings" close to what we later find in rabbinic literature. Philo is tacit about the sequence between the Passover and the early evening tamid. ${ }^{\mathrm{I}}$

9 Cf. Milgrom I99I-2010: I968-1969.

Io The Passover is slaughtered about two minutes after sunset, taken to be midway between the first evening, starting when the sun becomes yellowish, and the second evening, ending with nightfall; cf. Jeremias I932: 80. When Nisan I5 is a Sabbath, the sacrifice is brought forward to c. $30 \mathrm{~min}$ after noon.

${ }^{11}$ LXX Num 28:4, 8; Exod I2:6; I6:I2; Num 9:3, I I (lacking in 9:5).

${ }^{\mathrm{I} 2}$ LXX Exod 29:39, 4I; cf. ó $\psi \varepsilon \dot{\varepsilon}$ "late in the day, at even": Exod 30:8.

I3 Cf. Harlé and Pralon I988: I88, about translation technique in LXX Lev: "Ce littéralisme est propre au Lévitique."

${ }^{14}$ Philo's Alexandrian predecessor, the Torah interpreter Aristobulus, according to a fragment deriving from the third-century Christian writer Anatolius and preserved by Eusebius,

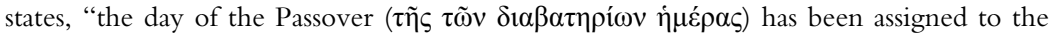
I 4 th of the month after evening ( $\left.\mu \varepsilon \theta^{\prime} \dot{\varepsilon} \sigma \pi \dot{\varepsilon} \rho \alpha v\right)$ " (Eusebius, Hist. Eccl. 7.32.I8). What Aristobulus wishes to show is that the sun and the (full) moon stand in opposition during this 
In his rewriting of the biblical law, Josephus maintains that the tamid was

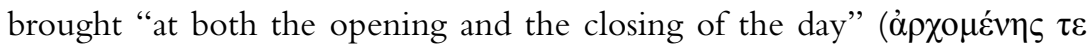

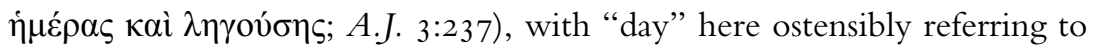
daytime. However, he is more specific about the timing of the second tamid when he describes concrete practice: during the siege under Pompey in 63 $\mathrm{BCE}$, the priests continued to offer the tamid "twice a day, in the morning

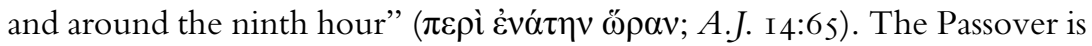
slaughtered "in the same way" as the Egyptian Passover, commemorating the latter, "because on that day God passed over them" (A.J. 2:3 I3; cf. 3:248). While in his rewriting of Exod I2, Josephus makes no mention of the time of slaughtering, he states in his description of a Passover during the Jewish War that the animals would have been killed "from the ninth hour to the eleventh" (B.J. 6:423). ${ }^{\mathrm{IS}}$ This earlier time bracket probably served to accommodate the large number of animals that were slaughtered in the Temple precincts. ${ }^{16}$ Does the mid-afternoon time for the tamid similarly reflect practical concerns?

The Mishnah (m. Pesah. 5:I), redacted in the early third century CE, views the tamid slaughtered at eight and a half hours and offered at nine and a half, which comes close to the time given by Josephus. On Passover eve, the tamid is brought forward by an hour: slaughtered at seven and a half and offered at eight and a half, with the Passover animal following, that is, from about the ninth hour (around 3 p.m.), ${ }^{17}$ on either a regular weekday or a Sabbath. ${ }^{18}$ However, if Passover coincides with Sabbath eve, the tamid is brought forward by a further hour: slaughtered at six and a half and offered at seven and a half, followed by the Passover animal. Clearly such early timing of both tamid and Passover addresses largely practical concerns, that is, to leave enough time for preparing the slaughtered Passover animal in advance of the Sabbath. ${ }^{19}$ Conceptually, this timing is justified by a particular

time. As is known, the visibility of the full moon begins with sunset; thus, "after evening" likely means "after sunset" here. Beyond the observation that Aristobulus, according to this fragment, reckons some time after sunset with Nisan I4, we cannot say anything specific about his envisioned timing for any part of the celebration.

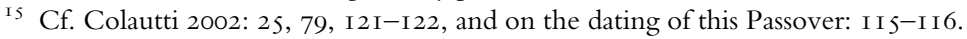

${ }^{\text {I6 }}$ Cf. Safrai and Safrai 2009: 209-2 I0; Tabory 2000: 87-88. This applies despite the possibility that Josephus's numbers are exaggerated; cf. Colautti 2002: I I 5-I I6 with n. 8I.

${ }_{17}$ The ninth temporal hour coincides with $3 \mathrm{p} . \mathrm{m}$. at the time of the vernal and autumnal equinoxes.

I8 As to the sequence of tamid and Passover, Werman 20II: 303-304 suggests (against Yadin) that it is also preserved in the Temple Scroll and that I I QT ${ }^{\mathrm{a}}$ I $7: 6-7$ merely requires that the Passover be brought before the afternoon grain and drink offering.

19 The animal should preferably be completely roasted but at any rate had to be in the oven before Sabbath; cf. m. Pesah. 6:I; t. Pesah. 7:I; Jeremias I932: 83-84. 
understanding of bein ha- 'arbayim: the "two evenings" are taken as the beginning and the end of the afternoon. This reasoning is developed in the Mekhilta de-Rabbi Ishmael (probably redacted in the second half of the third century CE), ${ }^{20}$ where the period for slaughtering the Passover animal is said to be from the sixth hour onward, when the day turns toward evening; this is corroborated with a quotation from Jer 6:4, according to which "noon" is the time from which "the day declines, the shadows of evening lengthen." In this context, the Mekhilta also provides an attempt at harmonizing the timing "between the two evenings" with the times given in the second - yet different - main biblical Passover passage, Deut I6: "in the evening, at sunset, the time you departed from Egypt" (Deut I6:6). The beginning of the departure is assumed with the sixth hour of the day, for which Exod I2:4 I is referred to, saying that all companies of the Lord went out "on this day itself." According to R. Shim'on ben Yohai, the times as given in Deut I 6:6 must be reversed: the time of departure corresponds to the slaughtering, sunset to roasting, and evening to eating the Passover animal. ${ }^{22}$

A particular interpretation of "between the two evenings" can be found in the Book of Jubilees. ${ }^{23}$ The section on the Passover in this text from the middle of the second century BCE, originally written in Hebrew yet fully transmitted only in Ethiopic and partly also in Latin, ${ }^{24}$ starts with the command (Jub. 49:I):

Remember the commandments which the Lord gave you regarding the passover so that you may celebrate it at its time ${ }^{25}$ on the fourteenth of the first month, that you may sacrifice it before evening ( $z a$-'enbala yemsay), and so that they may eat it at night (ba-lèlit) on the evening ('ama mesêt) of the fifteenth from the time of sunset.

The slaughtering must take place in the afternoon of the fourteenth, while the roasted meat is consumed after nightfall on the fifteenth. It is clear that

20 Cf. Stemberger 201 I: 282.

2I Mek. Pisha Bo' 5 (I7-I 8 Horovitz and Rabin); cf. Siphra 'Emor pereq I I: I (Iooa Weiss).

22 Mek. ibid.; Midr. Tannaim Deut I6:6 (92 Hoffmann); the passage was later also added as an alternative explanation (davar 'aher) to Siphre Deut. I33 (I90 Finkelstein); cf. Epstein I957: $72 \mathrm{I}$. In the main text, Siphre Deut. (ibid.) quotes both R. Eliezer and R. Aqiva, who interpret the phrase "in the evening, at sunset" (Deut I6:6) as follows: "in the evening you slaughter, at sunset you eat," with "sunset" apparently indicating the earliest time for eating; cf. Shemesh I996: 7 n. I9. Here, "evening” must refer to the hours of the afternoon.

23 On Jubilees' understanding of "between the two evenings" cf. also Werman 20 I I: 30 I-304. On the use of passages from Exod I2, Lev 23, Num 9, and Deut I6 in Jub. 49, see HalpernAmaru 2007.

24 The Ethiopic text and the English translation used here follow VanderKam I989.

25 See Num 9:2-3; cf. Num 28:2. 
this requires a beginning of the new day some time in the evening. While this passage develops the timing "in the evening," "at the time of sunset" from Deut I $6: 4,6,{ }^{26}$ another passage explicitly explains the phrase "between the two evenings" and specifies further the times for slaughtering and consuming the meat (Jub. 49:IO-I2):

The Israelites are to come and celebrate the passover on its specific day - on the fourteenth of the first month - between the evenings (ba-me'kala mesyātāt), from the third part of the day ('em-sälestā la- 'elat) until the third part of the night ('eska sâlestā la-lèlit). For two parts of the day (keffē makfaltā la-'elat) have been given for light (la-berhān) and its third part (wa-sālestä) for the evening (la-mesett). (I I) This is what the Lord commanded you - to celebrate it between the evenings (ba-me'kala mesêtatat). (I2) It is not to be sacrificed at any hour of the daylight but in the hour of the boundary of

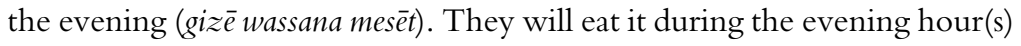
(ba-gize mesêt) until the third part of the night. Any of its meat that is left over from the third part of the night and beyond is to be burned.

To this, we can add a third passage (Jub. 49:I9):

At the time when the house is built in the Lord's name in the land which they will possess, they are to go there and sacrifice the passover in the evening when the sun sets, in the third part of the day. ${ }^{27}$

The period of daylight is thus divided into three parts. The third part of the day has been given to the evening, and it is during this time that the animal has to be slaughtered, at "the boundary of the evening." Apparently, "between the evenings" 28 is here interpreted to mean the bracket of time between the beginning of the "evening" part of the day and the "evening hour(s)," reckoned with the night, during which the meat is eaten. This bracket of time is "when the sun sets." This is also coherent with 49:I, according to which the meat is consumed only "from the time of sunset." While the period of sacrifice starts around the eighth hour, ${ }^{29}$ Jubilees maintains a strong connection with the setting of the sun and may thus distance itself from the view, variously affirmed,

${ }^{26}$ Cf. Halpern-Amaru 2007: ${ }^{\star} 82-\star 84$.

27 Kugel 20I2: I98-200 reckons Jub. 49:IO-I2 among the passages introduced by an interpolator. There is no room to discuss this issue here; suffice it to note that I do not consider Kugel's criteria for identifying the hand of the interpolator compelling. In the present case, Kugel has to admit (202) that 49:I9, not from the interpolator, agrees with the "third part of the day" as time for slaughtering the Passover.

28 Note however that the Latin translation does not render the term accordingly but simply uses variations of "evening": ad uesperam (Jub. 49:IO), in uespertino (49:I I), and in uespertina (49:I2).

29 That is, c. 2 p.m. around the time of the vernal equinox. 
as we have seen, by Philo, Josephus, and the rabbinic tradition, that "between the evenings" starts from midday and that the slaughtering may be practically brought forward to the early hours of the afternoon. ${ }^{30}$ Yet, Jubilees accepts that "between the evenings" is not strictly limited to the time around sunset, as we observed for the Samaritan tradition. It appears, on the one hand, to harmonize the scriptural heritage with its double emphasis on evening/sunset (Deut) and "between the two evenings" (Exod, Lev, Num) and, on the other hand, to negotiate between scriptural heritage and Second Temple practice, which knew wider margins of "between the two evenings." It does so with a unique, "literal" reading of "between the two evenings" that refers one of these "evenings" to the last "daylight" part of the day, the other one to the "night" part of the following day.

It is debated whether the "third part of the night" refers to the first third (inclusively counted) ${ }^{3 \mathrm{I}}$ or the last third (exclusively counted).$^{32}$ I deem the former solution preferable, in which the periods are adjacent to one another: Jubilees here deploys a conceptual reinterpretation of "between the two evenings" that takes the first evening as the last third of the day, during which the animals are slaughtered, and the second evening as the first third of the night, ${ }^{33}$ during which their meat is eaten. ${ }^{34}$ Contrary to the scriptural deployment of the phrase "between the two evenings," which relates only to the sacrifice, Jubilees extends the meaning to encompass both the slaughtering and the consumption. A similar concept might be found in the dictum of one Ben Bathyra in the Mekhilta: "Give an evening to slaughtering it and an evening to eating it." ${ }^{35}$ The limitation of meat consumption to the first third

${ }^{30}$ Cf. Kugel 20I2: 200; in contrast, Werman 20II: 304 plays down the differences regarding the time of slaughter.

${ }^{31}$ E.g. Werman 20II: 302, 305; Kugel 2012: 199-200.

32 E.g. Albeck I930: I3; Halpern-Amaru 2007: ${ }^{\star} 86-\star 87$. That this count could not be inclusive is clear because it otherwise would designate the very end of the night unlikely in view of the comparative texts mentioned later.

33 The assumption of adjacent periods (both inclusively reckoned) is more satisfactory than coupling the third part of the night as the "evening of the night" (exclusively reckoned) with the "evening of the day" (inclusively reckoned), as does Halpern-Amaru 2007: ${ }^{8} 86-\star 87$.

34 The Latin translation seems to corroborate this by speaking of meat consumption "in the third part of the night" (tertia noctis) rather than "until the third part" (Jub. 49:I2). The statement in the same verse about meat "that is left over from the third part of the night and beyond" may then either be taken as "from the end of the third part of the night and beyond" or, if the Latin is correct that leaves out "and beyond," simply as "from the third part," i.e. from the period of consumption. Pace VanderKam I989: 3 I9 (trans.), Latin hoc here may be pleonastic (quod ... hoc ... "what ... that ...") rather than reflecting the misconstruction of a Hebrew equivalent of "and beyond."

${ }^{35}$ Mek. Pisha Bo' 5 (I 8 Horovitz and Rabin). Alternatively, Ben Bathyra might combine the different rabbinic views regarding "evening" discussed earlier. 
of the night reflects stringency beyond Exod I2:IO, which merely says that nothing must be left over until morning. In rabbinic texts, we find a debate between the majority of the sages, who hold that it was permissible to eat the Passover animal until the early dawn, and R. Eliezer, who gives midnight as a limit. The shorter margin was eventually accepted to prevent transgression ("to make a fence around the Torah"; see m. 'Abot I:I). ${ }^{36}$

\section{Public Announcement of the Approach and the End of the Sabbath}

According to several sources, a series of trumpet blasts marked the approach of the Sabbath. The first one to describe this is Josephus (B.J. 4:582) ${ }^{37}$; he says that the zealots under John of Giscala, enclosed in the Temple area, built four towers. One of them

was erected above the roof of the priests' chambers ( $\pi \alpha \sigma \tau o \varphi$ opí $\omega v)$, at the point where it was custom for one of the priests to stand and to give notice,

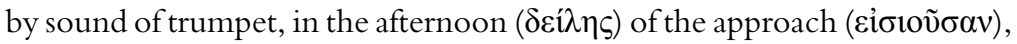
and on the following evening ( $\pi \varepsilon \rho i \dot{\varepsilon} \sigma \pi \dot{\varepsilon} \rho \alpha v)$ of the close ( $\tau \varepsilon \lambda \varepsilon \sigma \theta \varepsilon i \tau \sigma \alpha v)$, of

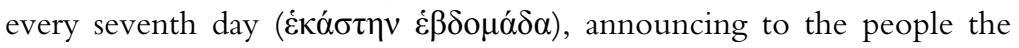
respective hours for ceasing work and for resuming their labors.

It is interesting to find a trumpet signal also after the end of the Sabbath. This suggests that Saturday night was deemed a time in which "labors" (है $\rho \gamma \alpha)$ would be resumed. ${ }^{38}$ What is remarkable is the element of social coordination

${ }^{36}$ Mek. Pisha Bo' 6 (I9 Horovitz and Rabin); Siphre Deut. I33 (I9o Finkelstein); m. Pesah. Io:9; t. Pesah. I:34 [= 2:22]; y. Ber. I:I, 3a; b. Pesah. I2ob; Tg. Ps.-J. on Exod I2:8. R. Eliezer builds his argument on a gezerah shawah regarding the term "night" (לילה) for the eating of Passover (Exod I2:8) and God's slaying the firstborn (Exod I2:I2; cf. II:4; I2: 29-3I). This points to an apotropaic understanding of the annual Passover that was not generally shared; cf. Shemesh I996: 5-9. The Temple Scroll intriguingly does not give a temporal limit within the night (I IQT ${ }^{\text {a }}$ 7:8-9).

37 Trans. Thackeray, LCL (spelling adapted).

${ }^{38}$ Mark I6:I-2 suggests that trade resumed on Saturday night: the women "bought"

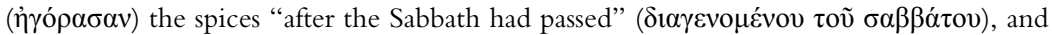
they came to Jesus's tomb "early in the morning of the first day of the week." While the evidence for shops opening in the evening is limited in rabbinic texts (but see m. Taan. I:6 regarding shops opening on Monday evening during a sequence of public fasts), there are references to "waiting for darkness at the (Sabbath) limit" (mahshikhin 'al ha-tehum) to conduct business, bring in fruit, or care for the needs of a bride or a dead body, after the Sabbath has ended (m. Šabb. 23:3-4; t. Šabb. I7[18]:IO-I3; b. 'Erub. 39a; b. Šabb. I 50a-I5Ia). Some purposes of such waiting are forbidden, others permitted: according to m. Šabb. 23:3; t. Šabb. I7[I8]:I3, Abba Sha'ul set up the rule that for anything one may say on Shabbat one may also wait for the darkness at the Sabbath limit. 
by means of the signal marking the beginning and the end of the rest. The connection with the Temple and the priests creates a common public context for observing the set time and keeping Shabbat, independent of the different sects and groups within ancient Judaism that otherwise follow their own legal and practical traditions about the Sabbath. The details Josephus gives for the locations of the towers are not fully clear. However, the pastophoria, priestly chambers mentioned by this name also in the Greek scriptures, ${ }^{39}$ were likely situated at the western side of the Temple enclosure. ${ }^{40}$

Even so, the precise times given by Josephus are ambiguous. Josephus speaks of a signal marking out the approach and the end of the $\dot{\varepsilon} \beta \delta$ o $\mu \alpha$, a term frequently used in the Hellenistic Jewish writers for "Sabbath." The temporal expression used for the approach is $\delta \varepsilon i ́ \lambda \eta$, "afternoon," that concerning the end of the Sabbath, $\pi \varepsilon \rho \dot{~} \dot{\varepsilon} \sigma \pi \dot{\varepsilon} \rho \alpha v$, "around evening." As to the latter, we may assume that the signal would have been issued at or, perhaps more appropriately, after nightfall. As to the former, there is reason to assume that Josephus refers to a signal issued some time before the actual beginning of the seventh day, to allow the people to cease work and prepare for the Sabbath rest.

A similar understanding of the trumpet signals is suggested by several references in rabbinic texts. Thus, $\mathrm{m}$. Sukkah $5: 5$, discussing the number of trumpet blasts on various days and festivals in the year, states: ${ }^{4 I}$

And on Sabbath eve they used to add a further six, three to cause the people to cease labor and three in order to separate between holy and profane.

The Tosefta here clearly comments on this mishnah and fills in a number of details (t. Sukkah 4:I I-I 2$):^{42}$

"Three to cause the people to cease from labor" - how so? The officer of the synagogue (hazzan ha-knesset) takes trumpets and ascends to a rooftop at the highest place in town. He starts to blow: those close to town cease (from labor), those close to the (Sabbath) limit enter and come into the limit; they

39 See LXX I Chron 9:26; 23:28; 26:I6; 28:I2; 2 Chron 3I:II; I Esdr 8:58; 9:I; I Macc 4:38, 57; Isa 22:I5; Jer 42:4; Ezek 40:I7, 38. Where Hebrew text is extant, it is often לשכה (but no building is referred to in Isa 22:I5 MT); in I Chron 26:I6, LXX appears to translate לשכה לכת לכת

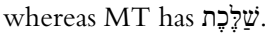

40 The text from Josephus can be compared with an archaeological discovery that came to light during the excavations at the Temple Mount. Not far from the southwestern corner, an inscription connected to a corner piece of the top ridge of the Herodian Temple enclosure was found, for which the following restoration has been proposed: le-beit ha-teqi 'ah le-hakh[riz] "For the house of trumpeting, to announce." See Mazar I978: 30, 34-35.

${ }^{41}$ The translation follows Danby I958.

${ }^{42}$ Trans. LD, based on MS Erfurt. Cf. for the issue Elbogen I9I I: II-VII; Gilat I992: 3 I6-3 I 7. 
would not enter immediately but wait until all come, and then enter all at the same time. When does he (himself) enter? After he would have filled a barrel of water, fried a fish and lit the (Sabbath) lamp for himself. (I2) "Three to separate between the holy and the profane" - how so? The officer of the synagogue takes a trumpet and ascends to a rooftop at the highest place in town. He starts to blow: a person transfers a dish from the stove, stores a hot kettle away and lights the lamp for himself. When he stops blowing, he does not even store away a hot kettle but sets it down on the earth, he does not even put a lamp in his hand onto the lamp-stand but sets it down on the earth.

Although an "officer of the synagogue" is occasionally mentioned for the Temple Mount (e.g. m. Yoma 7:I), the Tosefta reads as if a procedure similar to the one Josephus reports for Jerusalem would take place in any (larger?) town. It is doubtful that this would reflect historical reality during Second Temple times; more likely, the Tosefta might here be seen as "democratizing" a Jerusalem institution. Whether this corresponds to actual practice during the rabbinic period is not fully clear; some scattered references to shofar signals on Sabbath eve may suggest this. ${ }^{43}$ Be that as it may, the three trumpet blasts inviting people to cease from labor were staggered and came in intervals. At the beginning of the second set of three blasts, domestic preparations still seem possible, whereas by the last blast they need to be interrupted. However, the order, particularly the position of kindling the Sabbath light, is not entirely clear here. The Babylonian Talmud gives different details for the process (b. Šabb. 35 b): ${ }^{44}$

Our Rabbis taught: Six blasts were blown on the eve of the Sabbath. The first, to cause the people to cease labor on the fields; the second, to cause the city and shops to cease (labor); the third, for the lights to be kindled: that is R. Nathan's view. R. Judah the Nasi said: The third is for the tefillin to be removed. Then there was an interval for as long as it takes to bake a small fish, or to make a loaf stick to the oven, and then a teqi'ah, a teru' $a h$ and a teqi'ah were blown, and one began the Sabbath rest.

We note that the time of the kindling of Sabbath lights is still debated. ${ }^{45}$ While the first three blasts here call for a staggered cessation of work, the actual Sabbath

${ }^{43}$ Cf. Gilat I992: 3 I6-3 I7, citing references from both Babylon and Eretz Israel. Note, however, that "trumpets," as mentioned in the Tosefta, are the privilege of the Temple (cf. y. Roš Haš. $3: 4,58 \mathrm{~d}$ ), though in b. Sukkah 34a trumpets and shofars are viewed as interchangeable.

${ }_{44}$ ET of b. Šabb. follows the Soncino translation, with some adaptations.

45 The Babylonian Talmud ibid. adduces a further variant of the tradition, attributed to the Amora Samuel (de-be Shmu'el), but in Talmud editions mistakenly assigned to the school of R. Ishmael (Epstein 2000: 2I2-2 I4): the first blast ceases work on the fields, the second closes the shops, and the third is the signal to remove hot water and pots, as well as light the lamp. The remainder is the same as in the first variant. 
rest is preceded by the second set of three blasts "blown in rapid succession." ${ }_{46}$ The interval between the first and second set of three blasts is given as the cooking time for small items of food. This is significant since that is what Jewish women would be doing on Friday afternoon: preparing the Sabbath meal. The stoves and ovens were still hot and would be used until close to the beginning of the Sabbath rest. These rabbinic texts, then, distinguish between the time given to preparation for the Sabbath and the beginning of Sabbath rest proper; the latter probably occurred rather close to the actual beginning of the day. ${ }^{47}$ This distinction between time given to preparation and actual Sabbath rest should also be considered in other testimonies, such as Augustus's exemption of Jews in Asia Minor from being called to court or from standing security to appear in court

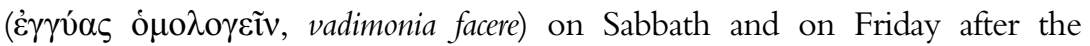
ninth hour, that is, after around 3 p.m. This does not suggest that Jews in the Diaspora would have started their actual Sabbath rest at that time..$^{8}$

\section{Early Start of Sabbath Observance}

In contrast to the texts discussed so far, there is evidence that Jews at certain times and places started their actual Sabbath rest somewhat in advance of the day. Thus, the Damascus Document (CD-A IO:I4-I7), a medieval copy of a Second Temple text also found among the Qumran scrolls, states about the onset of Sabbatical rest:

No-one may do, on the (I5) sixth day, labor from the time that the orb of the sun will be (I6) distant from the gate (by) its fullness; for this is what he said: "Guard the (I 7 ) day of the Sabbath to sanctify it."

This text takes the observable distance of the sun from "the gate" as the indicator of the time from which no labor should be done on Friday evening. ${ }^{49}$ There is a long-standing debate over what is referred to by

${ }^{46}$ So the comment in the Soncino translation ad loc. (I66 n. 2).

${ }^{47}$ Cf. Safrai and Safrai 2008: 29.

$4^{8}$ Josephus, A.J. I6:I62-I65 (edict by Augustus); Doering I999: 30I-302. Contra Gilat I992: 3 I 7 , who holds that the Asian Jews started to observe Sabbath several hours before sunset.

49 This passage presents a prima facie obstacle to the theory of the late Shemaryahu Talmon that a solar calendar would feature a reckoning of the day from morning, not evening. Talmon I958: 193 attempted to resolve this difficulty as follows: "the copyist" of CD-A, "whether a Karaite or a Rabbanite, altered the ancient wording" to bring it in line with the beginning of Shabbat in the Middle Ages. According to the later version of this theory, the original reading would have been: "no one may do, on the day of the Sabbath, labor from the time that the orb of the sun will be distant from the gate (by) its fullness" (Talmon I960: 394-395; cf. 2004: 88-92). Talmon reasoned that this would be the orb of the rising sun over the city gate on Saturday morning. However, such a late start of Sabbatical rest relative to the 
"gate" here: it might be either the city gate ${ }^{50}$ or a celestial gate. ${ }^{5 \mathrm{I}} \mathrm{I}$ have elsewhere argued that the second solution, first proposed by Louis Ginzberg, is more convincing and that the first one suffers from two problems: first, it is unclear which gate would be in view, since the group associated with the Damascus Document Sabbath code may have lived in various places, not all of which necessarily had walls and gates; second, it remains open at what distance the observer is taken to stand from the relevant gate, since it will obviously make a difference if one is five, fifty, or five hundred yards away. ${ }^{52}$ The reference to Neh I3:I9, sometimes invoked here, ${ }^{53}$ is problematic, since here the phrase "when the gates of Jerusalem threw shadows" does not depend on a precise position of the setting sun, which is, however, needed in our case. ${ }^{54}$ It is therefore preferable to think of the celestial gate into which the sun sinks at the horizon. In recent years, this solution has gained plausibility by a better understanding of the notion of heavenly gates in the

beginning of daylight would sit uncomfortably with the sect's otherwise strict Sabbath regulations, as attested by CD-A IO:I4-II:I8. In addition, the theory of scribal change remains speculative. Pace Talmon 2003: $83-87$, I do not think that CD-A Io: I9, with its reference to "issues of labor or work to do next morning" (le-mashkim), points to an end of Sabbatical rest in the morning. This may simply be a reference to issues one would want to, or could only, pursue the morning after, such as going on a journey, traveling by ship, or any activity that would require continuation during daylight. More generally, the order of day and night in IQS IO: Io or of the activities in IQS IO:I3-I4 (cf. Talmon I958: I 89; Saulnier 20I2: $2 \mathrm{I} 6-2 \mathrm{I} 7$ ) is indecisive for the question of the beginning of the day since it may follow the cycle of activities from awakening to bedtime, perhaps - thus far can be conceded - with an emphasis on daylight. Most importantly, however, the 364-day calendar that is presupposed in many texts from Qumran is - contra Talmon - not a solar, but a schematic calendar, so it does not structurally prioritize the day over the night; it is only Jubilees that shows a solar emphasis (Jub. 6:32; cf. Ben-Dov and Saulnier 2008: I25, I36-I 38), and there can be no doubt that Jubilees affirmed a beginning of the day with evening (see $\mathbb{\$} 2$ ).

so E.g. Gilat I992: 258-259, who thinks of a western gate in Jerusalem (see n. 52) or the city in which the sectarians reside.

SI Thus the majority of earlier scholars; see the list in Doering I999: I 34 n. 80. Schiffman I975: $84 \mathrm{n}$. I remains undecided.

52 Doering I999: I 33-I 38. As to Gilat's suggestion (n. 50) that Jerusalem is in view, it should be noted that the so-called first wall, which, coming from the southwestern hill, bent toward the Temple Mount roughly at today's Jaffa Gate, did not have a western gate. Another possibility would be a gate on the Temple Mount; here the potential difference in distances would be reduced, though still be an issue.

53 Especially by Talmon 2003: 9I; 2004: 2I-23. On Talmon's peculiar understanding of the passage see n. 49. It should be stated that Neh I 3:I9 speaks of preparation for the Sabbath by closing the city gates in the later afternoon and not necessarily of the time when obligatory Sabbath rest began; contra Ta-Shma I983: 323 .

54 To be sure, the Talmudim tell of situations where people are advised to take the position of the sun over specific landmarks as a marker of time, but here the position of these people is known to those involved as well; see e.g. b. Šabb. 35 b; y. Ber. 4:I, 7c. 
Astronomical Book of Enoch. ${ }^{55}$ While lacking the complexity of the latter, the passage in CD-A Io:I4-I7 might well refer to the position of the sun above the heavenly gate it enters at sunset. To be sure, there may be weather conditions or topographical features such as mountains that make it impossible to see the sun stand above the horizon in the west; but this problem could be resolved by referring to corresponding time markers in such conditions, for which we have evidence in other sources. ${ }^{56}$ In any event, the Damascus Document requires abstention from work from a few minutes before sunset and about half an hour before the end of what is now called "civil twilight," which may serve us here as an approximate marker, from which onward one may speak of "darkness": by then, first magnitude stars have become visible and daylight has receded considerably. ${ }^{57}$

This text, then, suggests that the precise start of the Sabbath was not of primary concern, as already a small portion of Friday is subject to the behavioral mode relevant for the day, that is, Sabbatical rest. A similar concept is found in rabbinic texts. In the Siphra, it is initially derived from extending the fast on Yom Kippur beyond the limits of this day, both before and after. ${ }^{58}$ As the passage in the Siphra clarifies, this extension also applies to the Sabbath and further holidays, and it means that "you add from the profane to the holy." The aspect of an additional rest is initially called tosephet mela'khah "addition to (the ban on) labor" (Siphra ibid.) but later becomes known under the name tosephet shabbat "addition to the Sabbath." In tannaitic midrashim, the exegetical justification for this is found in the dual wording of the Sabbath commandment in the two versions of the Decalogue: “'Remember' [Exod 20:8] and 'Guard' [Deut 5:I2] - remember before it, and guard after it; hence they said: one adds from the profane to the holy." " We note that the passage in the Damascus Document relates the phrase "Guard the Sabbath, to sanctify it" to the stretch of time

55 I En. 72:I-5 features a double set of six gates; although no Aramaic text has been preserved for the section, the concept of gates through which the sun enters and exits is integral to the synchronistic system in the Aramaic fragments of the Astronomical Book from Qumran. On the gates cosmology of the Astronomical Book cf. now Ratzon 2015.

${ }^{56}$ See the advice given for cloudy days in b. Šabb. 35 b.

57 The end of "civil twilight" is reached when the center of the sun is $6^{\circ}$ below the horizon. The sun's position of one diameter above the horizon implies a height of $0.75^{\circ}$ above the horizon, but one has to take the "refraction" of the sun into account. A calculation for the cardinal points and the latitude of Jerusalem yields $29 \mathrm{~min} 5$ Os for the equinoxes and between $33 \mathrm{~min}$ and $34 \mathrm{~min} 20$ for the solstices. I wish to thank Dr. Björn Voss, LWL-Museum für Naturkunde, Münster, for the relevant information.

${ }^{58}$ Siphra 'Emor pereq I 4:7-9 (I02a Weiss); b. Yoma 8 Ia.

59 Mek. Ba-hodesh (Yitro) 7 (229 Horovitz and Rabin), Mek. Šim. Yitro (I48 Epstein and Melamed) (both on Exod 20:8) and Midr. Tannaim on Deut 5:I2 (2 I Hoffmann). 
before the Sabbath. There is thus a similar exegetical sensitivity to that of the later rabbis, though not the same exegetical solution: the rabbinic version appears to have further reflected on the implications of the difference between the Exodus and the Deuteronomy Decalogue and considered the end of the Sabbath as well, in line with its more comprehensive midrash halakhah.

However, it is unclear how much time would have been added before and after the Sabbath according to the rabbinic texts quoted. Moreover, it is also unclear how widely this view was initially accepted. For example, in y. Šeb. I:I, 33a, it is clearly stated that one is entitled to work on both Sabbath eve and New Year's eve "until the sun sets." To be sure, the Talmudim and midrashim state that some rabbis began Shabbat early, though this was an issue of personal style and piety, not a legal requirement. ${ }^{60}$ In addition, Talmudic sources continue to mention the idea of tosephet shabbat, although they do not normally state how much time one must add, and they also provide evidence that the addition practiced by some was actually minimal at best. ${ }^{61}$ Only later, in medieval Ashkenaz, do we find fixed public - and much longer - periods of tosephet shabbat, reflecting that the sun sets so late in summer that it would be difficult to wait with the lighting of lamps and the Sabbath meal. ${ }^{62}$

\section{Ambiguities Surrounding the Beginning of the Sabbath}

In contrast to the sources discussed earlier, the Mishnah does not mention tosephet shabbat at all. ${ }^{63}$ Instead, in m. Šabb. 2:7 we read:

There are three things that a person must say in his house on the eve of the Sabbath with (approaching) darkness ('im hashekhah): Have you tithed? Have you made an 'eruv? ? $^{64}$ Light the lamp. If it is doubtful whether it is darkness or not, one does not tithe certain (non-tithed) items (wadai) and dip the vessels and light the lamps. But one tithes uncertain items (demai), makes an 'eruv and stores hot water.

${ }^{60}$ Cf. y. Ber. 4:I, 7c; Ber. R. Io:8 [84-85 Theodor and Albeck] (R. Haninah ben Dosa). Cf. also the paraenetical warning - certainly without any legal implications - that no blessing will be on work done after the minhah on Friday (b. Pesah $50 \mathrm{~b}$ ).

${ }^{61}$ Cf. Gilat I992: 3I 8-320, though assuming that the old practice, which would have been strict in his view, was relaxed.

${ }^{62}$ See Ta-Shma I983.

${ }^{63}$ Cf. also Safrai and Safrai 2008: 3 I-36.

${ }^{64}$ A symbolic meal deposited before Shabbat, whereby a courtyard shared by two or more parties becomes a common domain into which each participating party is allowed to carry objects. 
This corroborates what we have suggested previously with respect to the trumpet blasts, namely, that it would have been quite common to continue with one's preparatory "labors" until quite close to the Sabbath. From this mishnah, it emerges that "im hashekhah "with (approaching) darkness" is slightly before the time when "it is doubtful whether it is darkness or not"; during the latter, only actions not prohibited by the Torah on Sabbath are allowed, such as tithing demai, making an 'eruv or storing hot water, whereas actions prohibited by the Torah, such as lighting lamps on Sabbath, are already banned. ${ }^{65}$ This in turn implies that according to this text, the legally binding beginning of the Sabbath was taken to be "darkness": it is only from then that forbidden labor had to stop.

A similar situation emerges from the debates between the Houses of Hillel and Shammai on the starting of processes continuing on their own, such as soaking dyes in water or drying flax in an oven: according to the House of Shammai, such processes may only be started before the Sabbath if they are also completed mi-be- 'od yom "while it is still day" (m. Šabb. I:5-6, 8). The House of Hillel, however, permits all of these, provided they are initiated "im ha-shemesh "during sunlight" (m. Šabb. I:8). Both schools agree that the beams of the oil press may be loaded with weights 'im hashekhah "with (approaching) darkness" but that meat, an onion, or eggs may not be fried at that time unless they are completely done before the Sabbath (t. Śabb. I: 20-2 I; cf. m. Šabb. I:9-IO). ${ }^{66}$

In sum, early rabbinic texts suggest that the Sabbath was begun at "darkness." Around sunset, "with (approaching) darkness," was the last opportunity for certain activities. In the period between sunset and darkness, "biblically" prohibited activities were no longer practiced. This intermediary period of time is called bein ha-shemashot, "twilight" (literally "between the suns"), in some early rabbinic texts. ${ }^{67}$ The problem with this period is that it is difficult to define. When precisely the Sabbath as well as other days started

${ }^{65}$ Cf. the rule recorded at t. Šabb. 2:9.

${ }^{66}$ Safrai and Safrai 2008: I04 give practical reasons for the agreement of the schools (and the respective deviation of one of them from its usual approach) in these two latter rulings. Cf. also t. Šabb. I:23 with further activities, such as channeling water to a garden, putting ointment on an eye or frankincense on coals on Sabbath eve "with (approaching) darkness." Cf. also the prohibition that an artisan go out with his tool samukh la-hashekhah "close to darkness": m. Šabb. I:3; t. Šabb. ı:8.

${ }^{67}$ See m. Nid. I:7; 6:I4; I0:2; m. Zabim I:6; t. Zabim I:I 3; m. Šabb. I9:5; Siphra Sherașim parashah II:2 (58c Weiss); m. Ker. 4:2; t. Ker. 2:I5; Mek. Shabbeta Wa-yaqhel I (346 Horovitz and Rabin); Siphra Hovah parashah 5:2 (20a-b Weiss); Hovah parashah I2:I (26c Weiss); Siphre Zut. Num 9:3 (258 Horovitz). Milgrom I99I-20I0: I969 refers to M. Jastrow's explanation of the term as "between the two services, between the rulership of the day and that of the night." 
was hard to establish experientially. Early rabbinic texts and traditions provide a few, albeit limited, pointers as to delimiting this period. Thus, in t. Ber. I:I, the "visibility of the stars" (șe't ha-kokhavim) is taken as a "sign" for the point from which one may say the evening Shema 'Yiśra'el, which is identified with the time of the Sabbath eve meal (see $\$ 6$ ). The Talmudim refer to early rabbinic traditions that classify the color of the sky: when the eastern sky is red it is certainly daylight (yom); when it is silver-colored it is twilight (bein ha-shemashot); and when it has become black, the zenith as well as the horizon, it is night (layla). ${ }^{68}$ The Talmudim then try to establish further criteria for differentiating between daylight, twilight, and nightfall, such as the number and size of visible stars or the distance one manages to walk until nightfall. However, the issue remains debated, so that the Jerusalem Talmud invokes the coming of Elijah, who will say, "That is twilight," and the Babylonian Talmud provides two definitions, one earlier for Sabbath observance and one later for the allowance of terumah consumption (after purification), assigning to each issue the more stringent option. ${ }^{69}$ In sum, the precise transition to the Sabbath remains a problem for the practitioner, and it is not sufficiently clarified in the early rabbinic (tannaitic) period.

\section{The Role of Meals}

In this context, the celebration of meals at the onset of the Sabbath may have had a mitigating role. Importantly, in this respect, in the early tannaitic period there would have been no prayer assembly in the synagogue marking the beginning of the Sabbath. Instead, the seventh day would have been welcomed during a common meal, ${ }^{70}$ which took place somewhat later than on other days, when dinners, especially of the elite, were held as early as around the ninth hour. ${ }^{71}$ According t. Ber. I:I, R. Meir identifies the time from which the evening Shema 'Yiśra'el may be recited with the time when the meal inaugurating the Sabbath is usually held, whereas the (other) Sages identify it with the time when the priests are entitled to eat terumah (cf. m. Ber. I:I). The latter is clearly after sunset: the priests must eat terumah in a status of ritual purity; but to acquire this status they have to await sunset after their purification (cf. e.g. Lev I5:I-II, I6, I8). As we have seen, however, there are discussions about the precise time of eating terumah.

${ }^{68}$ So y. Ber. I: I, 2b. Cf. the variant in b. Šabb. 34 b.

${ }^{69}$ See y. Ber. I:I, 2a-c; b. Šabb. 34b-35b. Cf. also b. Pesah. 94a.

${ }^{70}$ Cf. Elbogen i9i i: VII-IX; Gilat I992: 328.

${ }^{71}$ See e.g. b. Pesah. Io7b (King Agrippa), further t. Ber. 5:I-2 (and see later). For GrecoRoman practice cf. Klinghardt I996: 45 . 
At any rate, the Jerusalem Talmud states that according to tannaitic teaching, the two time markers point roughly to the same period of time. ${ }^{72}$

Moreover, the context of $m$. Šabb. 2:7 quoted earlier $(\$ S)$ clearly points to a domestic setting, in which the meal would have been prepared: the "tithe" mentioned in this situation can only refer to ingredients of the meal, and the 'eruv is a symbolic meal deposited between neighbors in their shared courtyard before Shabbat. These preparatory activities, including the lighting of the lamps, are the domain of women, but this mishnah suggests that the paterfamilias would have monitored them. The lighting of the lamps, already mentioned by Seneca (first century CE) as a Jewish practice on the Sabbath, ${ }^{73}$ has the dual character of a custom and a commandment. It is not absolutely necessary to light the lamp, as the continuation in m. Šabb. 2:7 shows: if one is too close to darkness, the lighting is discouraged because of the possibility that the Sabbath may have already begun. In addition, the use of lamps would have been a powerful custom illuminating the unusually late meal at the beginning of Shabbat and aptly expressing the joy of the day. ${ }^{74}$ On the other hand, the lighting of the lamp was considered a commandment, applicable to women, which could be "transgressed." "75

According to the Tosefta, rabbis of the third tannaitic generation (of Usha) engage in debate about the continuation of a meal on Sabbath eve (t. Ber. 5:2):

Ma'aśeh about Rn. Shim'on ben Gamli'el, R. Judah and R. Yose, who were reclining at Akko and the day became holy over them. Rn. Shim'on ben Gamli'el said to R. Yose, Let us interrupt for the Sabbath. He (R. Yose) said to him, Every day you prefer my words over R. Judah's, and now you are preferring R. Judah's words over mine ... He (Rn. Shim'on) said to him, If so, then let us not interrupt, so that they may not thus establish the halakhah in Israel. And they said that they did not move away thence until they established the halakhah according to R. Yose.

${ }^{72}$ Cf. y. Ber. I:I, 2a. However, the Jerusalem Talmud goes on to problematize this: whereas the priests' eating of terumah happens "while it is still daylight and the stars are there" (i.e., shortly after sunset), it is claimed that the Sabbath meal takes place about one or two hours later. This betrays a significant shift over against the earlier tannaitic practice: for the later (amoraic) sages in Palestine, the evening prayer in the synagogue precedes the meal, which is therefore held much later than in tannaitic times, except perhaps for scattered hamlets, where people prefer to go home while it is still daylight (ibid.).

73 Seneca, Ep. 95.47.

${ }^{74}$ Although the House of Shammai tended to disallow processes to continue on their own on Shabbat (see before n. 66), they accepted the use of Sabbath lamps as established custom.

75 Cf. m. Šabb. 2:6: lack of care with lighting the Sabbath lamps is one of the "transgressions" on account of which women die in childbed. 
The difference between R. Judah and R. Yose is succinctly expressed in the parallel to this section in y. Pesah. IO:I, $37 \mathrm{~b}$ and b. Pesah. Iooa, where this chreia or ma 'aśeh is prefaced with the following statement: "One interrupts for the Sabbaths - words of R. Judah. R. Yose says, One does not interrupt." What is established in this short narrative about a legal example is that meals may continue from Friday afternoon into the beginning of the Sabbath, and that one does not have to interrupt the meal for the Sabbath. R. Judah wants to distinguish more clearly between a Friday meal and the Sabbath; thus, he demands that guests who have reclined for a meal when the Sabbath approaches go to the bet ha-midrash "with (approaching) darkness" ( $i m$ hashekhah) and, upon their return, bless the "sanctity of the day" (qedushat hayom) over a glass of wine (t. Ber. 5:3). However, according to t. Ber. 5:4, reflecting the position of $\mathrm{R}$. Yose, one speaks, after the meal, first the benediction over the meal, referring to the Sabbath, and then blesses the "sanctity of the day." ${ }^{76}$ In t. Ber. 3:7, R. Eleazar b. Sadoq transmits, in his father's name, ${ }^{77}$ a brief prayer for Sabbath night as well as a benediction over the cup, "Blessed be the One who has sanctified the Sabbath day." Since the consumption of wine requires a benediction of its own, already the Houses of Hillel and Shammai are said to have debated whether the benediction over the day or over the wine comes first. ${ }^{78}$ In sum, the earlier tradition locates the qiddush, the blessing over wine and day, at the end of a meal during which the Sabbath had begun or, in rabbinic terminology, "become holy" (qadash). ${ }^{79}$

The celebration of a meal starting on Friday but honoring the Sabbath is also attested for the Jewish Diaspora by traditions connected with the elusive term cena pura. The evidence is circumstantial, but it can be inferred from the use of the term cena pura for Friday ${ }^{80}$ that it derived from the practice of a Jewish meal, presumably in honor of the Sabbath, on (late) Friday afternoon. ${ }^{81}$ According to William Horbury, Latin-speaking Jews used the

${ }^{76}$ Cf. also the tannaitic midrash Mekhilta de-Rabbi Ishmael, usually assumed to have been redacted around the time of the Tosefta, which states (Mek. Bahodesh [Yitro] 7): "they sanctify over the wine at its beginning," and then asks, "I have only the holiness of the daywhence the holiness of the night?" The midrash answers with reference to Exod 3I:I4, "and you shall keep the Sabbath," which is taken to be composed of night and day.

77 This R. Eleazar b. Sadoq might be a contemporary of the other rabbis or a grandfather of the same name; cf. Stemberger 201 I: 86, 93.

${ }^{78}$ Cf. m. Ber. 8:I; m. Pesah. Io:2; t. Ber. 5:25 [6:I]; t. Pesah. Io:2-3. The halakhah follows the House of Hillel, according to whom the blessing over the wine comes first.

79 E.g. t. Ber. 5:2, 3 .

${ }^{80}$ E.g. in Old Latin manuscripts at Judith 8:6; Matt 27:62; Mark I 5:42; Luke 23:54 for either

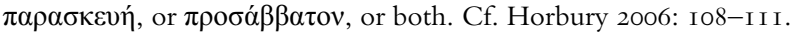

${ }^{81}$ Cf. Horbury 2006: I04. 
term cena pura for the Friday evening dinner and then for Sabbath eve. ${ }^{82}$ These Jews will have celebrated the onset of the Sabbath; yet, the name was applied to Friday.

For the Western Diaspora at the turn from the first to the second century, Plutarch mentions that Jews invite one another to drink wine on the Sabbath, presumably on Friday night; he interprets this as a form of Dionysian cult. ${ }^{83}$ Already earlier, and in Palestine, the Book of Jubilees repeatedly points out that the Israelites are to "eat, drink and keep Sabbath" on the seventh day (Jub. 2:3 I; cf. 2:2 I ;0:9, IO). As Horbury has argued, this sequence may point to the practice of inaugurating the Sabbath with a festive meal, although I find it difficult to accept Horbury's view that during daylight on the Sabbath hardly anything would have been eaten: ${ }^{84}$ Jubilees explicitly forbids fasting on the Sabbath (50:I2).

Similarly, the end of the Sabbath, and thus the beginning of the first day of the week, would have elapsed during a meal that was started on late Sabbath afternoon and continued until darkness, without marking out the precise time of the beginning to the new day. ${ }^{85}$ The havdalah, the ritual culminating in the separation between holy and profane after the end of Shabbat, was clearly part of a meal in the time of the Mishnah, as the introduction to m. Ber. 8: I explicitly states: "these are the controversies between the House of Shammai and the House of Hillel on the meal (ba-se 'udah)." The "Houses" in the late Second Temple period are said to have discussed the order of blessings during this ritual (m. Ber. 8:5).

In sum, before it became customary to pray in the synagogue at the onset and close of the Sabbath, ${ }^{86}$ Jews spent both the beginning and the end of the Sabbath days at dinner. These meals provided a framework for Sabbathconforming demeanor from before and until after the Sabbath, and participating in them absolved Jews from the need to determine the precise transition from one day to the other. Importantly, the rituals referring to the distinction

82 Cf. Horbury 2006: I09-I I I, discussing examples in Tertullian and Augustus.

83 Plutarch, Quaest. conv. 4.6.2 [Mor. 67I -672a] (trans. Clement and Hoffleit, LCL): "I believe that even the feast of the Sabbath is not completely unrelated to Dionysus. Many even now call the Bacchant Sabi and utter that cry when celebrating the god... The Jews themselves testify to a connection with Dionysus when they keep the Sabbath by inviting each other to drink and to enjoy wine; when more important business interferes with this custom, they regularly take at least a sip of neat wine."

84 Horbury 2006: I I7-I I 8. Some Jews seem to have fasted on the Sabbath, but this appears to me a minority position (Doering I999: 105-I07).

85 Cf. Elbogen i9I I: XI-XV.

86 As well as to attend sermons or lectures in the synagogue; cf. the anecdote of the woman eager to attend R. Meir's sermons on Friday nights: y. Soțah I:4, I6d; Lev. Rab. 9:9 (I: I9I-I93 Margoulies). 
between sacred and profane time (qiddush, havdalah) were integrated into the grace after meals.

\section{Summary}

This chapter has focused on rituals and observations surrounding the transition from one day to the next, particularly from weekday to Sabbath or festival. It has emerged that "evening" is an ambiguous time and could variously refer to parts of the afternoon and the earliest part of the night. Also, the delimitation of "twilight," and thus the precise transition to Sabbath and festival, was difficult to establish and remained debated for a long time. One solution to these difficulties was to add notional time from the previous day, thereby creating a "buffer" that would prevent transgression of behavior specifically demanded for the day, such as the Sabbath, Yom Kippur, and other holidays. Related exegetical approaches in the Damascus Document and in rabbinic texts about the tosephet mela'khah take the phrase "Guard the Sabbath day" to mean such forward extension. However, there is evidence in rabbinic literature that many would have conducted "labor" until shortly before nightfall and therefore would not have accepted, or would have limited to a minimum, any addition of rest before the Sabbath proper. A useful framework was the celebration of a meal during which the new day began, which was customary in the early tannaitic period. Crucially, the meal would have been prepared and members of the household would have gathered some time before the day came to an end, thereby already allowing some control over appropriate festal behavior during the uncertain period of transition from weekday to holiday. The earliest tannaitic references to qiddush and havdalah connect the blessing over the day closely with a meal at home, and there is also evidence of meals on Friday afternoons and evenings in the Jewish Diaspora. Meals, therefore, provided an opportunity for rendering the legally relevant ambiguities of time practically irrelevant by a controlled domestic celebration.

\section{Bibliography}

Albeck, C. 1930. "Das Buch der Jubiläen und die Halacha." Bericht der Hochschule für die Wissenschaft des Judentums in Berlin 47: $\mathrm{I}-60$.

Ben-Dov, J. 20Ir. "The Qumran Dial: Artifact, Text, and Context." In J. Frey, C. Claußen, and N. Kessler (eds.), Qumran und die Archäologie: Texte und Kontexte. Wissenschaftliche Untersuchungen zum Neuen Testament 278. Tübingen, 2 I I-237.

Ben-Dov, J. and S. Saulnier. 2008. "Qumran Calendars: A Survey of Scholarship I980-2007." Currents in Biblical Research 7: I24-I68. 
Birenboim, H. 1998. "The Laws of the Well-Being Sacrifice in the Miqșat Ma'aśeh [sic] Ha-Torah Scroll." Tarbiz 67: 24I-244 (in Hebrew).

Colautti, F. M. 2002. Passover in the Works of Josephus. Journal for the Study of Judaism in the Persian, Hellenistic, and Roman Periods, Supplement Series 75. Leiden: Brill, 2002.

Danby, H. (trans.). 1958. The Mishnah. Reprint. Oxford: Oxford University Press.

Doering, L. I999. Schabbat: Sabbathalacha und -praxis im antiken Judentum und Urchristentum. Texts and Studies in Ancient Judaism 78. Tübingen: Mohr Siebeck.

Elbogen, J. I9I I. "Eingang und Ausgang des Sabbats nach talmudischen Quellen." In M. Brann and idem (eds.), Festschrift zu I. Lewy's siebzigstem Geburtstag. 2 vols. Breslau: Marcus, I76-I87 [German part] (reprint Jerusalem, I97I/72).

Epstein, J. N. 1957. Introduction to Tannaitic Literature: Mishna, Tosephta and Yerushalmi. Ed. E. Z. Melamed. Jerusalem: Magnes Press; Tel Aviv: Dvir (in Hebrew).

Epstein, J. N. 2000. Introduction to the Mishnaic Text. 2 vols. 3rd ed. Jerusalem: Magnes Press; Tel Aviv: Dvir (in Hebrew).

Gilat, Y. D. 1992. Studies in the Development of the Halakha. Ramat Gan: Bar Ilan University (in Hebrew).

Halpern-Amaru, B. 2007. "The Use of the Bible in Jubilees 49: The Time and Date of the Pesah Celebration." Meghillot 5-6: ${ }^{\star} 8 \mathrm{I}-{ }^{\star}{ }_{\mathrm{IOO}}$.

Harlé, P. and D. Pralon. I988. Le Lévitique. La Bible d'Alexandrie 3. Paris: Cerf.

Horbury, W. 2006. "Cena pura and Lord's Supper." In idem, Herodian Judaism and New Testament Study. Wissenschaftliche Untersuchungen zum Neuen Testament I93. Tübingen: Mohr Siebeck, I04-I40.

Jeremias, J. 1932. Die Passahfeier der Samaritaner und ihre Bedeutung für das Verständnis der alttestamentlichen Passahüberlieferung. Beihefte zur Zeitschrift für die neutestamentliche Wissenschaft 59. Giessen: Töpelmann.

Kister, M. I999. "Studies in 4QMiqșat Ma'aśe Ha-Torah and Related Texts: Law, Theology, Language and Calendar." Tarbiz 68: 317-372 (in Hebrew).

Klinghardt, M. 1996. Gemeinschaftsmahl und Mahlgemeinschaft: Soziologie und Liturgie frühchristlicher Mahlfeiern. Texte und Arbeiten zum neutestamentlichen Zeitalter I3. Tübingen: Francke.

Kugel, J. 20I2. A Walk through Jubilees: Studies in the Book of Jubilees and the World of Its Creation. Journal for the Study of Judaism in the Persian, Hellenistic, and Roman Periods, Supplement Series I 56. Leiden: Brill.

Mazar, M. I978. "Jerusalem in the Time of the House of Herod in Light of the Excavations South and South-West of the Temple Mount." Cathedra 8: 29-4I (in Hebrew).

Milgrom, J. I99I-2010. Leviticus. Anchor Bible 3. 3 vols. New York: Doubleday; New Haven, CT: Yale University Press.

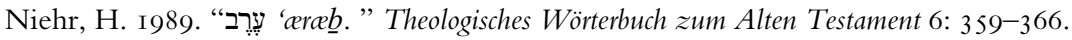

Ratzon, E. 20I 5. "The Gates Cosmology of the Astronomical Book of Enoch." Dead Sea Discoveries 22: 93-III.

Safrai, S. and Z. Safrai. 2008. Tractate Shabbat. Mishnat Eretz Israel, Moed A-B. Jerusalem: Lipshitz College Publishing House (in Hebrew).

Safrai, S. and Z. Safrai. 2009. Tractate Psachim. Mishnat Eretz Israel, Moed D. Jerusalem: Lipshitz College Publishing House (in Hebrew).

Saulnier, S. 20I2. Calendrical Variations in Second Temple Judaism: New Perspectives on the "Date of the Last Supper" Debate. Journal for the Study of Judaism in the Persian, Hellenistic, and Roman Periods, Supplement Series I 59. Leiden: Brill. 
Schiffman, L. H. I975. The Halakhah at Qumran. Studies in Judaism in Late Antiquity I6. Leiden: Brill.

Shemesh, A. I996. "Why this Passover?" AJS Review 21, 2:I-I7 (in Hebrew).

Stemberger, G. 20I I. Einleitung in Talmud und Midrasch. 9th ed. Munich: Beck.

Stern, S. 200I. Calendar and Community: A History of the Jewish Calendar, Second Century $B C E-$ Tenth Century CE. Oxford: Oxford University Press.

Tabory, J. 2000. Jewish Festivals in the Time of the Mishnah and Talmud. $3 \mathrm{rd}$ rev. and enlarged ed. Jerusalem: Magnes Press (in Hebrew).

Talmon, S. 1958. "The Calendar Reckoning of the Sect from the Judaean Desert." In C. Rabin and Y. Yadin (eds.), Aspects of the Dead Sea Scrolls. Scripta Hierosolymitana 4. Jerusalem: Magnes Press, I62-I99.

Talmon, S. I960. "Concerning the Calendar of the Judaean Desert Sect." Tarbiz 29: 394-395 (in Hebrew).

Talmon, S. 2003. "Sabbath Observance according to the Damascus Fragments: Evening to Evening or Morning to Morning?" Meghillot I: 7I-93 (in Hebrew).

Talmon, S. 2004. "Reckoning the Sabbath in the First and Early Second Temple Period From the Evening of the Morning?" In G. J. Blidstein (ed.), Sabbath: Idea, History, Reality. Beer Sheva: Ben Gurion University of the Negev Press, 9-32.

Ta-Shma, I. M. I983. "The 'Addition' to the Sabbath." Tarbiz 52: 309-324 (in Hebrew).

VanderKam, J. C. I989. The Book of Jubilees. 2 vols. Corpus Scriptorum Chistianorum Orientalium 5IO, 5I I. Leuven: Peeters.

Werman, C. 20I I. "The Festivals of the Year." In eadem and A. Shemesh, Revealing the Hidden: Exegesis and Halakha in the Qumran Scrolls. Jerusalem: Bialik Institute, 274-42 I (in Hebrew). 